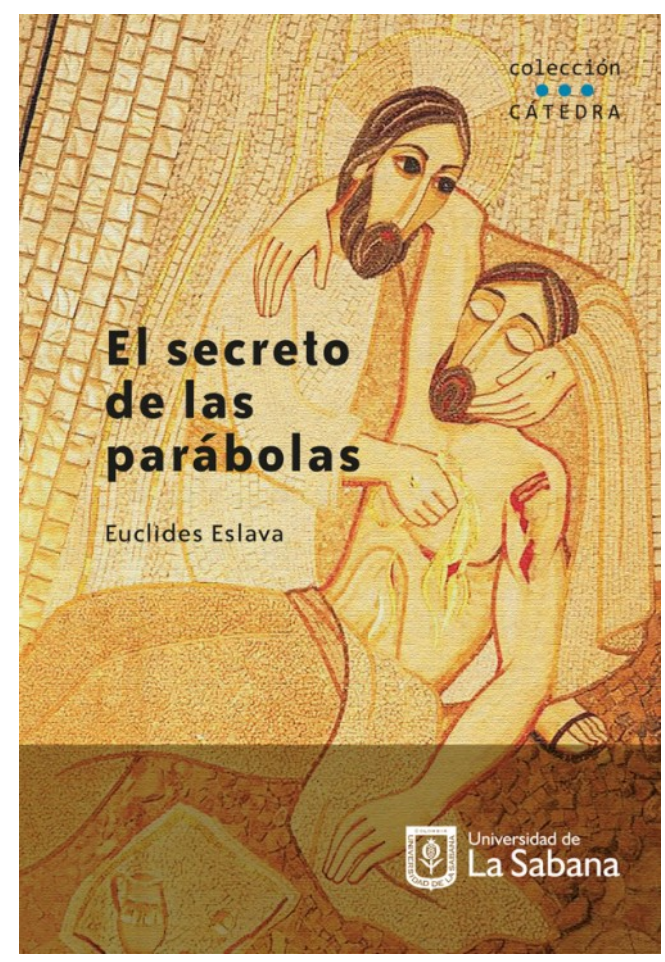

\title{
EL SECRETO DE LAS PARÁBOLAS
}

Por: Euclides Eslava Gómez

Formato: Impreso

ISBN: 978-958-12-0425-0

Facultad: Filosofía y Ciencias Humanas

Colección: Cátedra \# 10

DOI: https://doi.org/10.5294/978-958-12-0426-7

Idioma: Español

Precio en dólares: USD $\$ 13,50$

Número de páginas: 190

Palabras clave: enseñanzas, Jesucristo, oratoria, parábolas

\section{$\$ 36.000$}

\section{Reseña del Producto}

En este libro, aparece la nueva versión de las homilías más visitadas en el blog www.argumentaciones.blogspot.com, todas ellas sobre las parábolas del Evangelio. Es difícil explicar por qué razón provocaron ese interés: puede ser porque se trata de un género literario que sigue vigente y porque cada parábola nos dice algo a cada uno.

El objetivo de esta publicación es ayudar a hacer oración y a generar re exiones personales para la vida cotidiana, al hilo de la lectura del Santo Evangelio y de las explicaciones de grandes maestros de la espiritualidad cristiana. Y al tratar de que sea oración personal, más que lectura erudita, el autor es consciente de que el verdadero protagonista de ese diálogo es el Espíritu Santo en el alma de cada lector. Ese es otro secreto más de las parábolas...

\section{Información Adicional}

Peso: $1 \mathrm{~kg}$

Tamaño: $17 \times 24 \times 2 \mathrm{~cm}$

Sku: 9789581204250

\section{Tabla de contenido}

INTRODUCCIÓN

1. Las Parábolas del Reino

1.1. El sembrador

1.2. La lámpara y la medida

1.3. La cizaña, la mostaza y la levadura

1.4. El tesoro escondido, la perla preciosa y la red barredera

2. EL BUEN SAMARITANO

3. EL RICO INSENSATO

4. EL ADMINISTRADOR FIEL Y PRUDENTE 
5. LAS PARÁBOLAS DE LA MISERICORDIA

5.1. Oveja y Dracma perdidas

5.2. El hijo pródigo

5.3. El perdón de la mujer pecadora

6. LOS OBREROS DE LA VIÑA

7. EL ADMINISTRADOR INFIEL

8. LÁZARO Y EL EPULÓN

9. EL FARISEO Y EL PUBLICANO

10. LAS PARÁBOLAS DE JUICIO

10.1. Los dos hijos

10.2. Los viñadores homicidas

10.3. Parábola de los primeros puestos

10.4. Los invitados a las bodas

10.5. Parábola del siervo despiadado

11. LA LECCIÓN DE LA HIGUERA

11.1. La higuera estéril

12. LAS VÍRGENES NECIAS Y LAS PRUDENTES

13. LOS TALENTOS

14. LA VID Y LOS SARMIENTOS

15. EL BUEN PASTOR

16. CONSTRUIR SOBRE ROCA

BIBLIOGRAFÍA

ÍNDICE BÍBLICO

ÍNDICE ANALÍTICO 